\title{
Influenza A (H1N1) Virus
}

National Cancer Institute

\section{Source}

National Cancer Institute. Influenza A (H1N1) Virus. NCI Thesaurus. Code C80445.

A strain of swine influenza A virus identified as the causative agent of the swine flu epidemic of Spring 2009. It is highly contagious and susceptible to the antiviral medications. 